\title{
Detection and Identification of a Group 16SrIII-Related Phytoplasma Associated with Coffee Crispiness Disease in Colombia
}

\author{
Carlos A. Galvis, Jairo E. Leguizamón, and Álvaro L. Gaitán, Department of Plant Pathology, National Coffee \\ Research Center (CENICAFÉ), Manizales, Colombia; and Juan F. Mejía and Elizabeth Álvarez, Plant Pathology \\ Program, and José Arroyave, Virology Unit, International Center for Tropical Agriculture (CIAT), Cali, Colombia
}

\begin{abstract}
Galvis, C. A., Leguizamón, J. E., Gaitán, Á. L., Mejía, J. F., Álvarez, E., and Arroyave, J. 2007. Detection and identification of a 16SrIII-related phytoplasma associated with coffee crispiness disease in Colombia. Plant Dis. 91:248-252.

Coffee crispiness ("crespera"), a disease of uncertain etiology, has been endemic in coffee (Coffea arabica L.) plantations in Colombia for at least 60 years. Symptoms typically consist of bud proliferation, abundant short and narrow leaves, phyllody, floral abortion, monospermic fruit, and dwarfing of plants. In severe cases, coffee crispiness disease (CCD) can affect production significantly. In this study, association of a phytoplasma with CCD was indicated by the accumulation of Diene's stain, or 4',6-diamidino-2-phenylindole fluorescence, only in phloem of affected plant tissues. The presence of polymorphic phytoplasma cells in phloem sieve tube elements was confirmed by transmission electron microscopy. The disease was transmitted successfully by grafting symptomatic shoots from CCD-affected C. arabica plants onto young, healthy rootstocks; however, symptoms failed to develop after mechanical inoculation of young plants with extracts derived from diseased plant tissues. A nested polymerase chain reaction (PCR) assay employing primer pairs P1/P7 followed by FU5/rU3 amplified a 16S ribosomal DNA product $(941 \mathrm{bp})$ exclusively from DNA of diseased plants. Sequence and phylogenetic analysis of the nested PCR product identified the CCD phytoplasma as a new strain member of group 16SrIII (X-disease group). This is the first report of a phytoplasma infecting coffee plants.
\end{abstract}

Additional keywords: prokaryotes, trees

Coffee crispiness is a slow-spreading disease described in Colombian coffee plantations since 1940, endemic to limited areas throughout the country (32). It affects the physiological development of the aerial parts of the plant, especially the leaves and floral buds, causing leaf proliferation and phyllody, and also altering the fruit by increasing the percentages of monospermic berries. The curled leaves and massive vegetative growth that results in the branches give the local name "crespera" to the disease.

According to Mejía (20), coffee crispiness disease (CCD) was observed for the first time in the western Department of Antioquia and, by 1950, it was present in the central region of the country. Fernández (13) detected the disease in the southern Department of Huila and, years later, Valencia (34) confirmed the persistence of the disease in those areas. The disease affected similarly all the Coffea arabica cultivars planted in Colombia, which historically include Typica, Bour-

Corresponding author: A. L. Gaitán

E-mail: alvaro.gaitan@cafedecolombia.com

Accepted for publication 11 September 2006.

DOI: 10.1094/PDIS-91-3-0248

(C) 2007 The American Phytopathological Society bon, Caturra, and Colombia. From many observations, coffee crispiness is considered a mild disease that normally has no effect on yield or quality and is not transmitted by seed (33). In extreme cases, however, productivity can be dramatically reduced. Since 1997, farmers reported an increase in the symptom severity of coffee crispiness in places located over 1,500 m above sea level. This has been observed both in new plantings and in plants regenerated from stumps, a common practice in Colombian plantations. Because no etiology has been clearly established for coffee crispiness, control measures have been ineffective.

Throughout the years, CCD has been attributed to divergent causes, varying from viral problems (32) to micronutrient deficiency (33), mineral malnutrition (11), and physical and chemical soil limitations (6,34). Similarly, farmers have implicated herbicide toxicity in the development of crispiness symptoms. More recently, comparative symptomatology suggested the association of a phytoplasma with crespera (24). No evidence, however, has been provided to support any of these hypotheses.

As in other perennial crops, etiological studies in coffee can be lengthy, especially with diseases with long incubation periods or those which exhibit complex symptoms due to environmental or other interactions. Besides the traditional diagnostic methods, additional lines of evidence must be provided to determine the etiology of diseases of infrequently studied crops or of those causal agents that are difficult to isolate or culture, such as coconut decline (16), witches' broom in alfalfa (18), phyllody in wild cotton (8), and grape leaf roll (12).

The present work was intended to confirm the association of phytoplasma with CCD in Colombia and to establish its phylogenetic relationship based on the molecular characterization of the $16 \mathrm{~S}$ ribosomal (r)DNA. This is also the first report of a phytoplasma causing disease in the genus Coffea.

\section{MATERIALS AND METHODS}

Phytoplasma sources. During a 4-year period (1999 to 2003), symptomatic branches from $C$. arabica plants were collected periodically from around the Santa Rosa de Cabal region (Risaralda, Colombia) in 5-year-old coffee plantations regenerated from stumps. C. arabica cv. Caturra, obtained from seed of healthy plants, always was used as a negative control.

Transmission assays. Graft transmission. From CCD-affected plants, 10- to 15$\mathrm{cm}$-long terminal buds were grafted, employing a terminal V-shaped cut, on 100 healthy, 6-month-old $C$. arabica cv. Caturra plants. Fifty grafts were made with healthy material and used as controls. Shoots from the scion and the Caturra rootstock were observed for 45 days after inoculation.

Mechanical transmission by stumping. Twenty healthy, 6-month-old plants of $C$. arabica cv. Colombia were stumped $10 \mathrm{~cm}$ above the base of the stalk, and the leaf extract from symptomatic plants, macerated with $0.1 \mathrm{M}$ phosphate buffer ( $\mathrm{pH}$ 7.2), was applied on the exposed area. Controls consisted of 10 healthy cv. Colombia plants stumped at the same height and treated with sterile distilled water.

Mechanical transmission by wounding. Leaf extracts from symptomatic plants macerated with $0.05 \mathrm{M}$ phosphate buffer $(\mathrm{pH}$ 7.2) and Carborundum were applied with sterile cheesecloth on the leaves of 20 healthy, 6-month-old plants. Controls consisted of a similar macerate from healthy plants, applied on 10 plants of the same age.

Light microscopy. For 10 field plants showing advanced crespera symptoms, three branches were taken to hand pick leaves for the analysis. Applying the same 
criteria, 10 plants from grafting experiments were selected for examination.

4'6-Diamino-2-phenylindole staining. Petioles form healthy and diseased leaves between 5 and $8 \mathrm{~mm}$ long were fixed in $2.5 \%$ glutaraldehyde dissolved in $0.1 \mathrm{M}$ phosphate buffer, $\mathrm{pH} 7.0$, and conserved at $4^{\circ} \mathrm{C}$ until staining. Samples then were rinsed with water to remove the fixing solution, and immersed in 4',6-diamidino2-phenylindole (DAPI; Sigma D-9542) at $0.4 \mathrm{~g} \mathrm{ml}^{-1}$. The tissue was mounted into carrots and 15 - to $20-\mu \mathrm{m}$-thick slides were obtained. Fluorescence was examined in a Zeiss Jenamed epiflourescence microscope, with a set of one BP 365/11 excitation filter and an LP395 suppressor filter.

Diene's stain. Petioles from healthy and diseased leaves were fixed in Milloning solution (21) for $12 \mathrm{~h}$ and washed three times for $15 \mathrm{~min}$ in $0.1 \mathrm{M}$ phosphate buffer, $\mathrm{pH}$ 7.2. Samples were dehydrated through increasing concentrations of ethanol from 25 to $100 \%$, plus two additional steps in $100 \%$ acetone for $15 \mathrm{~min}$ each. Tissues were infiltrated with plastic using the standard Spurr mix diluted in acetone and ending with $100 \%$ plastic after $60 \mathrm{~min}$ at room temperature. Polymerization was carried out in $100 \%$ plastic at $65^{\circ} \mathrm{C}$ for 8 to $15 \mathrm{~h}$. Tissue slides, $20 \mu \mathrm{m}$ thick, were obtained using an LKB 2088 Ultratome (Bromma). One drop of $0.5 \%$ (vol/vol) Diene's dye was added to the tissue slides and washed with distilled water after $1 \mathrm{~min}$.

Transmission electron microscopy. Fifty petioles from diseased plants were collected and subsamples selected for analysis by transmission electron microscopy (TEM). The tissue fragments were cut into 1-by-2-mm pieces and prefixed in $2.5 \%$ glutaraldehyde $(0.1 \mathrm{M}$ phosphate buffer, $\mathrm{pH}$ 7.2) for $24 \mathrm{~h}$. The samples for electron microscopy were prepared by making thin (500-nm) sections with a diamond knife using an MT 6000 Sorvall Ultramicrotome (DuPont Co., Newton, CT). After post fixation and precontrasting in acetate, they were dehydrated in an ethanol series of $25,50,75,90$, and $100 \%$ (20 min each), continued with pure acetone (20 min, three times), and embedded in Spurr's resin $\left(60^{\circ} \mathrm{C}\right.$ for $\left.8 \mathrm{~h}\right)$. A previous 60-min infiltration with acetone-Spurr (1:1) was done to facilitate the entry of resin into the tissues. The ultrathin sections were mounted on copper grids (1 mesh), and observed on a JEOL 100CX transmission electron microscope (Japan Electron Optics Laboratory, Peabody, MA).

DNA extraction. Total DNA was extracted from leaves of CCD-affected field plants, rootstocks of grafted plants, and healthy coffee plantlets according to the procedure described by Bernatzky and Tanksley (3) with minor modifications. In short, $100 \mathrm{mg}$ of leaves ground in liquid nitrogen were immersed in $500 \mu \mathrm{l}$ of extraction buffer $(200 \mathrm{mM}$ Tris- $\mathrm{HCl}[\mathrm{pH}$
8.0], $70 \mathrm{mM}$ EDTA, $2 \mathrm{M} \mathrm{NaCl}, 20 \mathrm{mM}$ sodium metabisulfate, $2 \%$ cetyltrimethylammonium bromide, and $0.2 \% \quad \beta$ mercaptoethanol to avoid phenolic oxidation) and incubated in a water bath at $65^{\circ} \mathrm{C}$ for $1 \mathrm{~h}$. Next, one volume of phenol was added, mixed by inversion for $10 \mathrm{~min}$, and centrifuged at $16,110 \times g$ for $5 \mathrm{~min}$; and the supernatant was transferred to a new tube. The pellet was extracted with $500 \mu \mathrm{l}$ of chloroform and, after centrifugation at $7,400 \times g$, the supernatant was transferred to a new tube. DNA was precipitated by adding $250 \mu \mathrm{l}$ of $5 \mathrm{M}$ ammonium acetate and $750 \mu \mathrm{l}$ of isopropanol, and centrifuging for $25 \mathrm{~min}$ at $16,110 \times \mathrm{g}$. After rinsing with $1 \mathrm{ml}$ of $70 \%$ ethanol, and a last centrifugation at $16,110 \times g$ for $2 \mathrm{~min}$, the supernatant was discarded and, once dry, the pellet was resuspended in $50 \mu \mathrm{l}$ of TrisEDTA (TE) buffer (10 mM Tris $\mathrm{HCl}, \mathrm{pH}$ 8.0, and $0.1 \mathrm{mM}$ EDTA) and treated with 5

Polymerase chain reaction amplification. Three primer pairs from the $16 \mathrm{~S}$ rDNA were synthesized by Operon Technologies (Alameda, CA): P1 (9) and P7 (28), R16F2 and R16R2 (19), and FU5 and rU3 (29). A nested polymerase chain reaction (PCR) was performed as follows. A first amplification was carried out using Promega reagents (Promega Corp., Madison, WI) for a Master mix with $0.1 \%$ PCR buffer, $25 \mathrm{mM} \mathrm{MgCl}_{2}, 2 \mathrm{mM}$ dNTPs, and $\mathrm{Taq}$ polymerase at $0.1 \mathrm{U} / \mu \mathrm{l}$, in addition to $0.2 \mu \mathrm{M}$ primers $\mathrm{P} 1$ and $\mathrm{P} 7,5 \mu \mathrm{l}$ of coffee DNA at $20 \mathrm{ng} / \mu \mathrm{l}$, and distilled water to complete a volume of $25 \mu \mathrm{l}$. An amplification program was run on an MJ Research thermocycler, consisting of an initial denaturation at $94^{\circ} \mathrm{C}$ for $2 \mathrm{~min}$ and 35 cycles of $94^{\circ} \mathrm{C} 1 \mathrm{~min}, 55^{\circ} \mathrm{C}$ for $2 \mathrm{~min}$, and $72^{\circ} \mathrm{C}$ for 3 min. A final extension cycle was performed at $72^{\circ} \mathrm{C}$ for $10 \mathrm{~min}$. A second amplification was accomplished with $1 \mu \mathrm{l}$ of a $1 / 30$ dilution in sterile distilled water in a similar Master Mix containing either the $\mu \mathrm{g}$ of SIGMA RNAase per tube.

primer pair R16F2/R16R2 or FU5/rU3, running the same thermocycler program, except that the annealing temperature was changed to $50^{\circ} \mathrm{C}$. PCR amplification products were separated in $1 \%$ agarose gels in Tris-borate-EDTA buffer at $60 \mathrm{~V}$, stained with ethidium bromide, and recorded under UV light with a digital camera.

Molecular detection in grafted coffee plants. Leaf tissue from the rootstock of five plants grafted with diseased branches and from six 3-year-old plants from a commercial plot in the Santa Rosa de Cabal region (Risaralda, Colombia) was compared with healthy leaf tissue by amplification of the $16 \mathrm{~S}$ rDNA region of the phytoplasma. Primer pairs P1/P7 and FU5/rU3 were used for the nested PCR reaction, using coffee genomic DNA.

Cloning of PCR products and DNA sequencing. Amplified fragments in nested PCR reactions with primers FU5/rU3 were cloned in Escherichia coli JM109 using pGEM-T Easy vector (Promega Corp.) according to the manufacturer's instructions. Transformants were selected on blue/white color screening by plating on LB/ampicillin/IPTG/X-gal media. Positive inserts were observed by plasmid restriction with EcoRI and electrophoresis in $1.5 \%$ agarose gel. Three fragments from different plants were selected for sequencing by automated DNA sequencing at the Cornell Biotechnology Resource Center (Ithaca, NY); plasmid sequences were removed from each sequence and high-quality sequence data were collected. The sequence results were assembled in LaserGene MegAlign software (DNAStar), and the resulting consensus analyzed using BLASTn at the National Center for Biotechnology Information (NCBI; 1). The nucleotide sequence determined in this study was deposited in the GenBank database (NCBI, MD).

Phylogenetic analysis. From the GenBank, sequences of the 16S rRNA gene

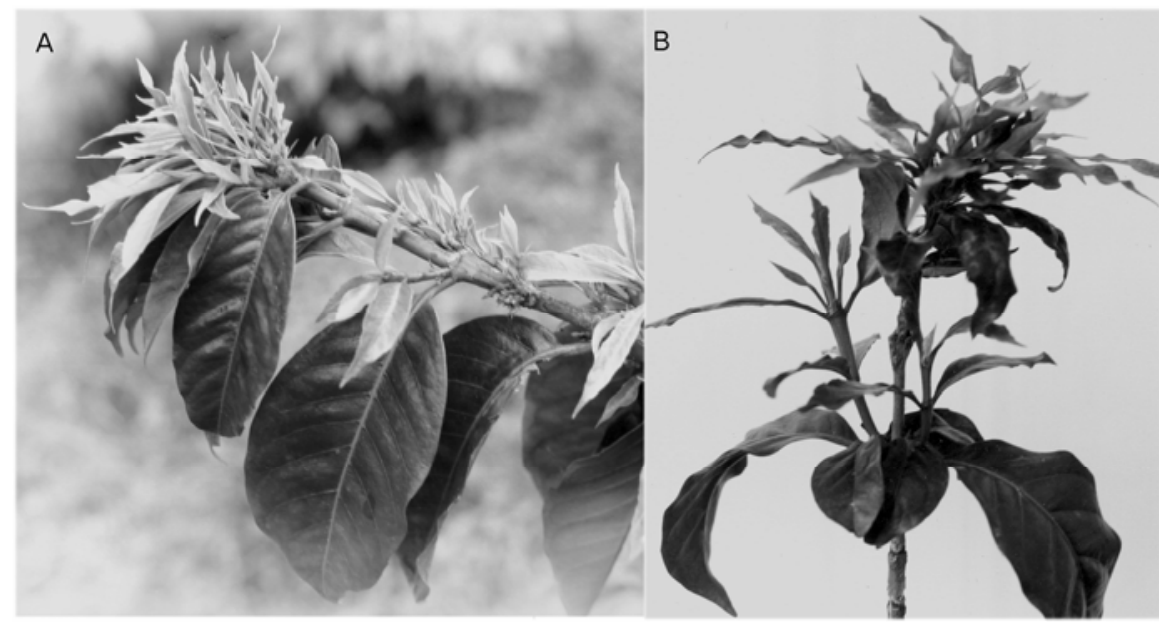

Fig. 1. Coffee crispiness symptoms under field and greenhouse conditions. A, Branch from coffee field plant exhibiting proliferation from the apical meristem. B, Coffea arabica cv. Caturra plantlet, grafted with crispiness-affected tissue, resulting in new branches on the rootstock showing symptoms. 
from coffee phytoplasma and 42 other phytoplasma strains representing $1216 \mathrm{~S}$ rRNA phytoplasma groups were downloaded, and a primary alignment was performed with ClustalX (31). The flanking nonconsensus regions were removed with BioEdit (15), leaving an effective comparison region of 908 bp. With the gap containing alignment, a phylip distance matrix was generated with ClustalX and a phylogenetic tree was constructed by the neighbor-joining method. The tree was visualized by using Tree-ViewPPC (26).

\section{RESULTS}

Transmission assays. Disease transmission was achieved only by grafting with diseased scions and $90 \%$ of the plants showed symptoms after 44 days. Symptoms consisted of necrosis of the first pair of axilar buds produced in the rootstock at the site of grafting, followed by proliferation of short and narrow leaves from the new buds developed in the next nodes (from top), with short internodal distances in the branches originating from them, resulting in symptoms similar to those

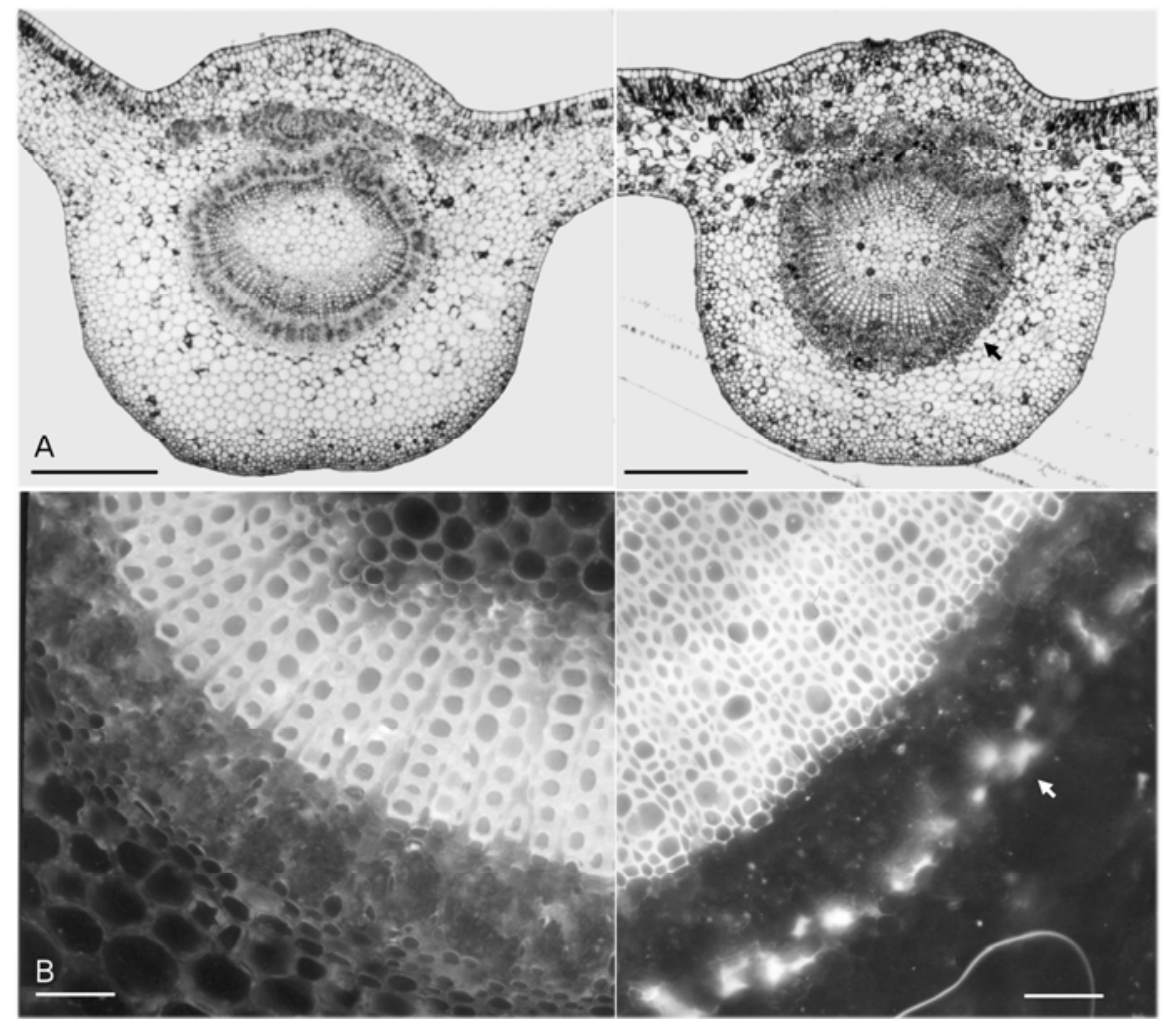

Fig. 2. Histological studies on transversal section of Coffea arabica cv. Colombia petioles affected by crispiness. A, Diene's staining under light microscopy; bars $=0.5 \mathrm{~mm}$. B, 4',6-diamidino-2phenylindole staining under fluorescent microscopy (BP 365/11 excitation filter and an LP395 suppressor filter); bars $=50 \mu \mathrm{m}$. The arrows indicate petiole phloem cells with differential coloration in healthy (left) and affected tissue (right).

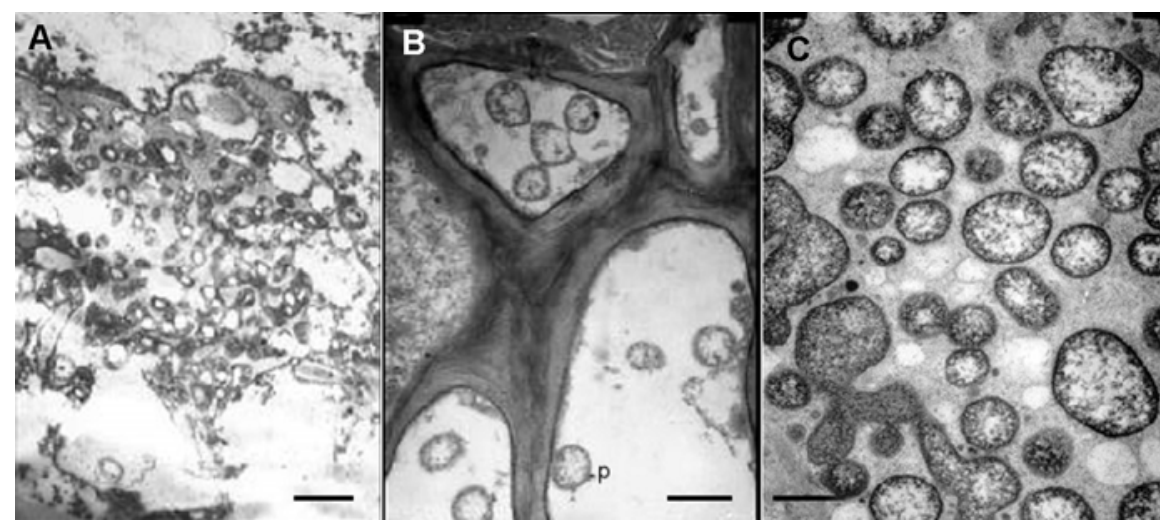

Fig. 3. Transmission electron microscopy of coffee petiole cells affected by crispiness. A, Pleomorphic bodies (arrow) inside a phloem cell of Coffea arabica cv. Colombia in affected tissue. B, Cell containing membrane-bound, phytoplasma-like bodies (p) within a vacuole. C, Phytoplasma cells (p) with a peripheral cytoplasm containing ribosomes and a central region of fibrillar material. Bars: $\mathbf{A}=2 \mu \mathrm{m}, \mathbf{B}$ $=500 \mathrm{~nm}$, and $\mathbf{C}=250 \mathrm{~nm}$.

observed in field plants (Fig. 1). Neither healthy nor affected scions produced any further budding during the observation period. In control grafts, the rootstock buds did not show any necrosis and never manifested crispiness symptoms. Accelerated bud formation occurred during the first 15 days in the plants grafted with diseased tissues, with symptoms appearing at day 30 .

Histological studies. Diene's staining permitted the visualization of affected tissue, with a deep blue coloration in phloem cells, that was absent in healthy tissues (Fig. 2A). Transmission was confirmed by positive staining in phloem of new buds of grafted plants. In phloem cells of the stalk and petioles, fluorescence was observed using DAPI, whereas no reaction was present in healthy tissue (Fig. 2B). TEM observations inside phloem cells of symptomatic tissues confirmed the presence of pleomorphic structures which lacked a cell wall. Those structures were similar to phytoplasmas (Fig. 3) and were absent from healthy tissue. Body shapes were highly variable, as were their size, ranging from 300 to $400 \mathrm{~nm}$ in length. As previously described by Siddique et al. (30) for phytoplasmas associated with Australian papaya dieback, the CCD phytoplasma cells were located in the vacuole, with numerous peripheral cytoplasm containing ribosomes and a central net of fibrils (that probably correspond to DNA).

Molecular detection in coffee plants. Clear amplifications of a 900-bp band were obtained from 16 infected field plants with primers FU5/rU3. Samples from six rootstocks with CCD symptoms produced less strong amplifications, but were still detectable. Negative controls and healthy tissues produced no amplifications (Fig. 4).

Sequencing of nested PCR products amplified from DNA of affected tissues resulted in a consensus 941-bp fragment (GenBank accession number AY525125) corresponding to the $16 \mathrm{~S}$ rDNA. When homologous regions of 12 phytoplasma groups were aligned (40 sequences), the resulting tree reproduced the current taxonomic groups, and the CCD sequence clustered with the $16 \mathrm{Sr}$-III group (data not shown), described as the $\mathrm{X}$-disease group by Lee et al. (19). Further analysis with 42 sequences described as belonging to the $16 \mathrm{Sr}$-III family, or with close sequence similarity, produced a radial tree for the family with four main branches (Fig. 5), with the coffee crispiness phytoplasma being one of the most distant sequences of the whole group, and where the phytoplasma causing "machorreo" in lulo or naranjilla (Solanum quitoense) was the closest, with a percentage divergence (D) of $0.012 \%$, in a cluster that also contained witches' broom of chayote (Sechium edule; $\mathrm{D}=0.015 \%$ ), and decline of garlic (Allium sativum; $\mathrm{D}=0.013 \%$ ). For the other branches, the most divergent sequences 
corresponded to Italian clover phyllody $(\mathrm{D}=0.023 \%)$, dandelion virescence $(\mathrm{D}=0.022 \%)$, Circium white leaf $(\mathrm{D}=$ $0.019 \%$ ), and sugarcane yellows ( $\mathrm{D}=$ $0.016 \%$ ) phytoplasmas.

\section{DISCUSSION}

Several lines of evidence indicate that a pathogenic agent is responsible for the disorder known as crespera in coffee plantations in Colombia. Comparative symptomatology, transmission to healthy plants by grafting, presence of adenine- and thymine-rich DNAs as detected by DAPI (27), as well as pleomorphic bodies inside phloem cells and detection of rDNA sequences similar to phytoplasmas led to the conclusion that one of these prokaryotes is responsible for the disease.

Coffee crispiness symptomatology matches numerous observations that indicate the interference phytoplasmas cause in the balance of nutrients and the alteration of protein and auxin synthesis (10), which in turn results in stunting and proliferations. There is difficulty in diagnosis when mild symptoms are present; trees can be tolerant to the presence of these organisms and symptoms can disappear during changing environmental conditions, leading to an apparent recovery already observed in other crops (22). In coffee plantations, it is normal to find either healthy new leaves on branches that are showing the disease, or healthy branches on symptomatic trees. Another source of confusion is the effect of herbicides, such as glyphosate, which is used in some plantations for weed control, that can result in alterations of vegetative buds, producing numerous long leaves.

For these reasons, plus the difficulty in isolating and culturing phytoplasmas, fulfillment of Koch's postulates is difficult and requires a complementation with molecular methods for detection in coffee. Such methods will allow epidemiological studies in historically endemic areas as well as new geographic zones where symptoms are observed. Molecular detection also will clarify the mechanisms of disease transmission and the presence of alternative hosts. However, research still is required to determine the distribution and concentration of the phytoplasmas throughout the plant, as well as for the best time for sampling. In our experience, phytoplasmas may occur at very low concentrations in coffee; thus, a sensitive method for detection is important. Nested PCR can detect concentrations as low as 51 cells per gram of plant tissue, a common situation in many genera and perhaps in coffee, in contrast with phytoplasma concentrations in plants such as Catharanthus roseus, which can reach up to $2.2 \times 10^{8}$ cells per gram of infected tissue (2).

The failure of mechanical transmission is consistent with the observations of phytoplasmal diseases in crops other than coffee. We suggest that an insect vector may be important in the epidemiology of the disease, which is the main means of transmission of other phytoplasmal dis- eases in nature (25), where the pathogen can exhibit persistent and propagative behaviors (5). One of the measures to control phytoplasma diseases involves the

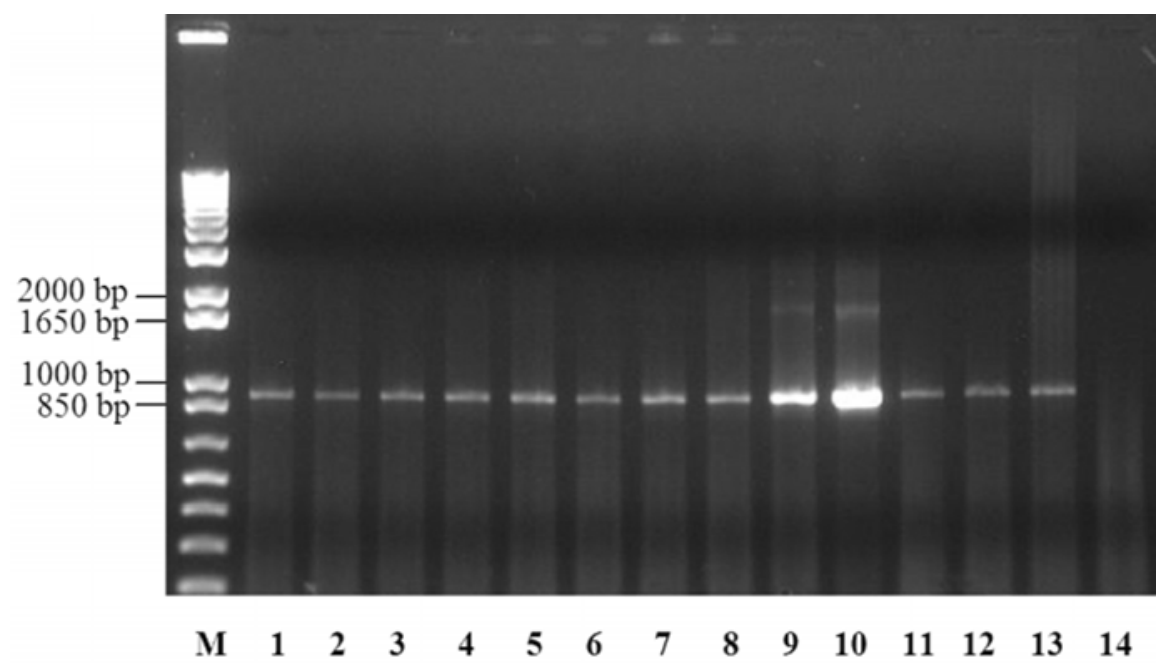

Fig. 4. Agarose gel separation of polymerase chain reaction products from nested amplification of a 941-bp band corresponding to the $16 \mathrm{~S}$ ribosomal (r)DNA. Lane $\mathrm{M}=$ molecular weight marker; lanes 1-4: rootstock from grafted coffee plants with symptoms; lanes 5-8: field coffee plant tissue exhibiting crispiness; lanes 9-10: cloned and sequenced crispiness phytoplasma rDNA; lanes 11-13: positive control (phytoplasma-infected Catharanthus roseus field plants); and lane 14: healthy coffee tissue.

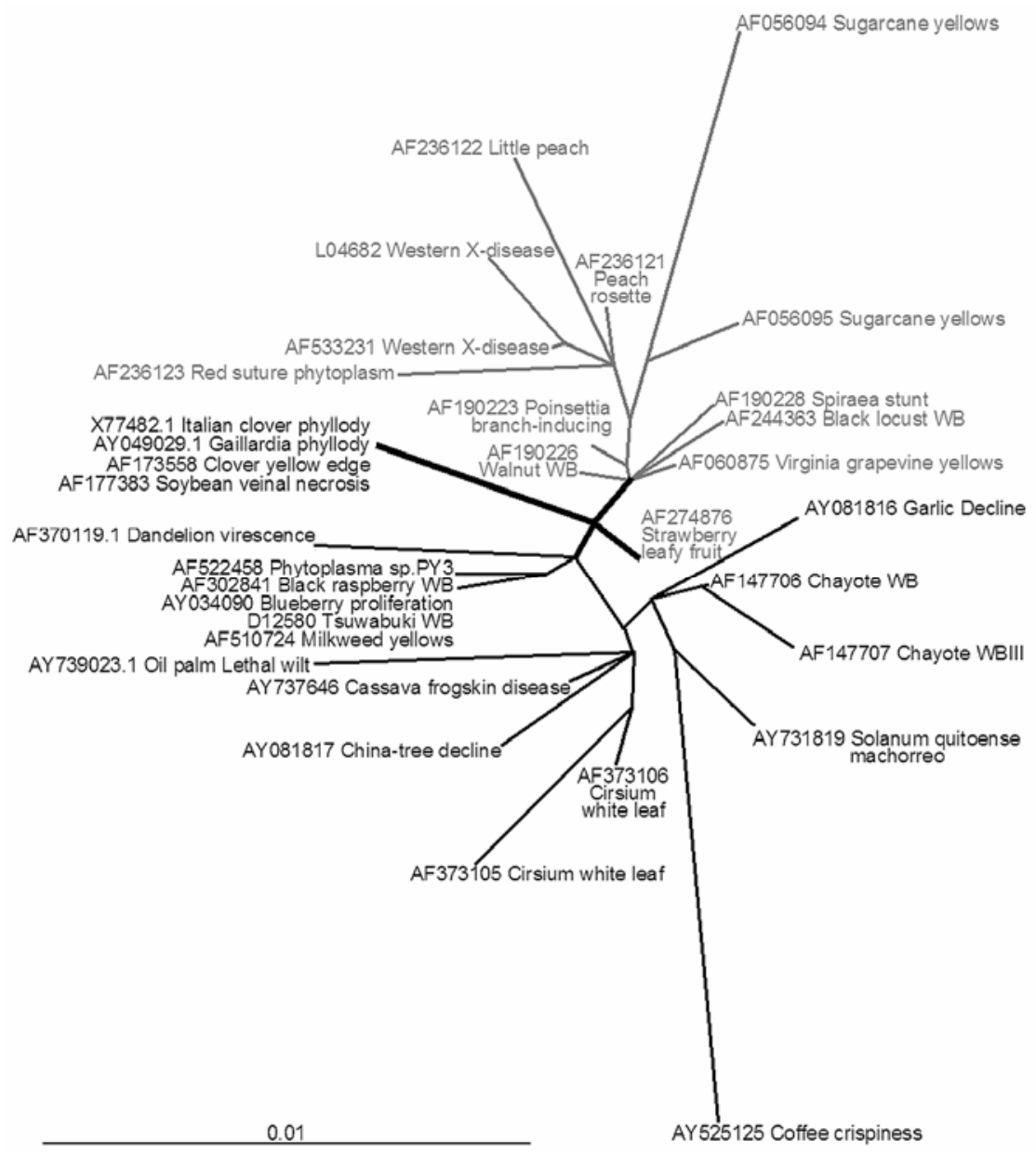

Fig. 5. Detailed organization of the $16 \mathrm{SrIII}$ (X-Disease) phytoplasma group based on ribosomal DNA sequences. The closest relative to the coffee crispiness phytoplasma corresponds to the agent of Solanum quitoense "Machorreo" phytoplasma, also isolated in Colombia. 
management of vector populations; therefore, we currently are studying the cicadellids present in coffee plantations. These insects either may be moving between the coffee fields and nearby crops or weeds or may complete their life cycles within the fields on coffee plants or on associated weeds.

The sudden outbreaks of the disease in past and recent years could be the result of a combination of the presence of the phytoplasma, the chemical weed control used in some plantations, and the known interaction between environmental conditions and vector populations $(4,7)$. The influence of El Niño-related weather changes in the Colombian coffee zone must be considered, in particular the recent $1997-98$ phenomenon.

The possible taxonomic association between the machorreo-causing phytoplasma and the CCD phytoplasma suggests the presence of a common ancestor in South America. However, coffee is an introduced species that has been on the continent for only the last two centuries. This leads to the hypothesis that coffee has become an alternative host of a phytoplasma. In fact, the limited distribution and moderate dispersal and virulence of crispiness agree with the pathogen behavior and may provide alternatives for disease control. Moreover, the chinaberry tree phytoplasma, reported in Bolivia (17), the chayote witches' broom from Brazil (23), and the garlic decline phytoplasma from Argentina (14) are in the same clade as the CCD pathogen.

Coffee crispiness or crespera is the first report of a phytoplasmal disease in the genus Coffea. As a new member of the 16 SrIII group, we propose the name coffee crispiness disease or CCD phytoplasma.

\section{ACKNOWLEDGMENTS}

This work was supported by the National Coffee Research Center (CENICAFÉ) as well as by funds supplied by the International Center for Tropical Agriculture (CIAT)

\section{LITERATURE CITED}

1. Altschul, S., Madden, T., Schäffer, A., Zhang, J., Zhang, Z., Miller, W., and Lipman, D. 1997. Gapped BLAST and PSI-BLAST: a new generation of protein database search programs. Nucleic Acid Res. 25:3389-3402.

2. Berges, R., Rott, M., and Seemuller, E. 2000. Range of phytoplasma concentrations in various plant hosts as determined by competitive polymerase chain reaction. Phytopathology 90:1145-1152.

3. Bernatzky, R., and Tanksley, S. 1986.Toward a saturated linkage map in tomato based on isozymes and random cDNA sequences. Genetics 112:887-898.
4. Blomquist, C. L., and Kirkpatrick, B. C. 2002. Frequency and seasonal distribution of pear psylla infected with the pear decline phytoplasma in California pear orchards. Phytopathology 92:1218-1226.

5. Bové, J., and Garnier, M. 2002. Phloem- and xylem-restricted plant pathogenic bacteria. Plant Sci. 163:1083-1098.

6. Carrillo, I. F. 1984. Estudio de la crespera. Pages 20-22 in: Federación Nacional de Cafeteros de Colombia. Centro Nacional de Investigaciones de Café. Sección de Química Agrícola. Informe Trimestral de Labores Octubre a Diciembre, Chinchiná, Colombia.

7. Cousin, M. T., Berges, R., Roux, J., Moreau, J. P., Hiruki, C., and Seemuller, E. 1999. Populus nigra L. Italica decline in France. Variability of the phytoplasma responsible for the disease in Europe: results and perspectives. Acta Hortic. 496:77-85.

8. D’Aquilio, M., Boarino, A, Bozzano, G., Marzachl, C., Roggero, P., and Boccardo, G. 2002. First report of phytoplasmas infecting swan plants (Gomphocarpus physocarpus) in Liguria, Italy. Plant Pathol. 51:796.

9. Deng, C., and Hiruki, S. 1991. Amplification of 16S rRNA genes from culturable and nonculturable Mollicutes. J. Microbiol. Methods 14:53-61.

10. De Oliveira, E., Magalhaes, C., Gomide, L., Vasconcelos, A., Souza, P., Oliveira, M., Cruz, I., and Schaffert, E. 2002. Growth and nutrition of mollicute-infected maize. Plant Dis. 86:945-949.

11. Drosdoff, M. 1956. Problemas de suelos y nutrición mineral en la producción cafetera de Colombia. La Crespera del café. Agric. Trop. 12:103-105.

12. Duduk, B., Ivanovic, M., and Dukic, N. 2003. First report of an elm yellows subgroup $16 \mathrm{SrV}$ $\mathrm{C}$ phytoplasma infecting grapevine in Serbia. Plant Dis. 87:599.

13. Fernández, B. O. 1978. Informe de la visita de reconocimiento de algunas áreas de la zona cafetera del Departamento del Huila con el fin de establecer experimentación regional. Centro Nacional de investigaciones de Café, Departamento de Biología y Suelos, Chinchiná, Colombia

14. Galdeano, E., Torres, L. E., Meneguzzi, N., Guzmán, F., Gomez G. G., Docampo, D. M., and Conci, L. R. 2004. Molecular characterization of $16 \mathrm{~S}$ ribosomal DNA and phylogenetic analysis of two X-disease group phytoplasmas affecting china-tree (Melia azedarach L.) and garlic (Allium sativum L.) in Argentina. J. Phytopathol. 152:174-181.

15. Hall, T. A. 1999. BioEdit: a user-friendly biological sequence alignment editor and analysis program for Windows 95/98/NT. Nucleic Acid Symp. Ser. 41:95-98.

16. Harrison, A. N., Myrie, W., Jones, P., Carpio, M. L., Castillo, M., Doyle, M. M., and Oropeza, C. 2002. 16S rRNA interoperon sequence heterogeneity distinguishes strain populations of palm lethal yellowing phytoplasma in the Caribbean region. Ann. Appl. Biol. 141:183-193.

17. Harrison, N. A., Boa, E., and Carpio, M. L. 2003. Characterization of phytoplasmas detected in chinaberry trees with symptoms of leaf yellowing and decline in Bolivia. Plant Pathol. 52:147-157.
18. Khan, A. J., Botti, S., Al-Subhi, A. M., Gundersen, R. D., and Bertaccini, A. F. 2002. Molecular identification of a new phytoplasma associated with alfalfa witches' broom in Oman. Phytopathology 92:1038-1047.

19. Lee, I. M., Dawn, E., Gundersen, D. E., and Bertaccini, A. 1998. Phytoplasma: ecology and genomic diversity. Phytopathology 88:13591366.

20. Mejía, F. R. 1950. Sanidad y defensa de las plantaciones de café en el país. Cenicafé 1:22 27.

21. Milloning, G. 1976. Laboratory manual of biological electron microscopy. Mario Saviolo, Vercelly, Italy.

22. Mittempergher, L., Sfalanga, A., Vibio, M., and Bertaccini, A. 1999. Phytoplasmas, Aceria bezzii and drought in declining European hackberry (Celtis australis L.). Acta Hortic. 496:87-91.

23. Montano, H. G., Davis, R. E., Dally, E. L., Pimentel, J. P., and Brioso, P. S. T. 2000. Identification and phylogenetic analysis of a new phytoplasma from diseased chayote in Brazil. Plant Dis. 84:429-436.

24. Moreira, L., Hord, M., Villalobos, W., Vasquez, V., Obando, J., and Rivera, C. 1997. Caracterización biológica y molecular del agente causal de la Crespera del café en Costa Rica. Page 409 in: Simposio Latinoamericano de Caficultura 18, Memorias, ICAFE-IICAPROMECAFÉ, San José, Costa Rica.

25. Namba, S., Kato, S., Iwanami, H., Oyaizu, H., Shiozawa, H., and Tsuchizaki, T. 1993. Detection and differentiation of plant-pathogenic mycoplasma-like organisms using polymerase chain reaction. Phytopathology 83:786-791.

26. Page, R. D. 1996. TREEVIEW: An application to display phylogenetic trees on personal computers. Comput. Appl. Biosci. 12:357-358

27. Razin, S., Yogev, D., and Naot, Y. 1998. Molecular biology and pathogenicity of mycoplasmas. Microbiol. Mol. Biol. Rev. 62:1094-1156.

28. Schneider, B., Seemuller, E., Smarth, C. D., and Kirkpatrick, B. C. 1995. Phylogenetic classification of plant pathogenic mycoplasma like organisms or phytoplasmas. Pages 369-380 in: Molecular and Diagnostic Procedures in Mycoplasmology, Vol. 1. S. Razin and J. G. Tully, eds. Academic Press, San Diego, CA

29. Seemuller, E., Marcone, C., Lauer, U., Ragozzino, A., and Goschl, M. 1998. Current status of molecular classification of the phytoplasmas. J. Plant Pathol. 80:3-26.

30. Siddique, A. B. M., Guthrie, J. N., Walsh, K B., White, D. T., and Scott, P. T. 1998. Histopathology and within-plant distribution of the phytoplasma associated with Australian papaya dieback. Plant Dis. 82:1112-1120.

31. Thompson, J. D., Gibson, T. J., Plewniak, F Jeanmougin, F., and Higgins, D. G. 1997. The ClustalX windows interface: flexible strategies for multiple sequence alignment aided by quality analysis tools. Nucleic Acid Res. 24:48764882.

32. Urhan, O. 1950. Algunas ideas sobre el problema de la Crespera. Cenicafé 1:29-35.

33. Urhan, O. 1952. Contribución al estudio de la Crespera. Cenicafé 3:17-24.

34. Valencia, G. 1983. La Crespera un disturbio fisiológico del cafeto. Av. Téc. Cenicafé 112:1-4 